\title{
ILLICIT ENRICHMENT DALAM PENEGAKKAN HUKUM PENGAMBILAN IKAN SECARA TIDAK SAH (ILLEGAL FISHING) DI WILAYAH PERAIRAN INDONESIA
}

\author{
Endiyono Raharjo, Rio Saputra \\ Program Magister Ilmu Hukum, Universitas Muhammadiyah Malang \\ Jl. Bandung No. 1 Kota Malang, Jawa Timur \\ Email : endiyonor@mail.com, rio_salim@yahoo.com
}

\begin{abstract}
With a sea area of more than 5.8 million $\mathrm{km}^{2}$ Indonesia into the fields were wet for the perpetrators of illegal fishing, but it is not only those involved in illegal fishing are committing exploitation of marine resources in it, due to ease and expedite actions of those involved in illegal fishing have interference from government officials and private entrepreneurs who help in exploiting marine resources in it. Illicit enrichment officials and private entrepreneurs in committing permudahan and facilitate the exploitation of marine resources by those involved in illegal fishing would be a bad precedent for officials and the private sector, which should keep and explore marine resources so that their needs and income that should belong to the state. Government that is supported by law enforcement in the rigor and candor regulations should be able to make the deterrent effect of government officials and private entrepreneurs who do illicit enrichment.
\end{abstract}

Keywords: Illegal Fishing, Illicit Enrichment, Government Officials, Private Entrepreneurs.

\begin{abstract}
Abstrak
Luas lautan seluas Indonesia 5.8 juta $\mathrm{km}^{2}$ Indonesia menjadi ladang basah bagi pelaku illegal fishing, tidak hanya itu tetapi juga melakukan tindak eksploitasi sumber daya laut di dalamnya.Untuk memudahkan dan melancarkan perbuatan illegal fishing ini, para pelaku melibatkan campur tangan dari pejabat pemerintah dan pengusaha swasta yang membantu dalam mengeksploitasi sumber daya laut di dalamnya. Illicit enrichment pejabat dan pengusaha swasta dalam melakukan upaya mempermudah dan melancarkan tindak pidana eksploitasi sumber daya laut bagi pelaku illegal fishing ini dapat menjadi preseden buruk bagi pejabat dan pihak swasta, yang seharusnya memiliki tanggungjawab terhadap upaya menjaga dan mengeksplorasi sumber daya laut. Ini dimaksudkan agar kekayaan sumber daya alam hayati di perairan laut Indonesia, dapat menjadi pendapatan yang menjadi milik negara. Pemerintah dapat tegas dalam penegakkan hukum karena didukung oleh penegak hukum dan ketentuan peraturan hukum yang ada dan seharusnya mampu memberikan efek jera (detterent effect) bagi para pejabat pemerintah dan pengusaha swasta yang melakukan illicit enrichment.
\end{abstract}

Kata kunci: Illicit Enrichment, Illegal fishing, Pejabat Pemerintah, Pengusaha Swasta.

\section{A. PENDAHULUAN}

Indonesia sebagai negara kepulauan (archipelago state), dikenal dengan keluasan perairannya yang disebut sebagai Negara maritim. Indonesia dinobatkan sebagai negara kepulauan terbesar pertama di Asia dan terbesar kedua di dunia. Fakta menunjukkan, berdasarkan data dari KKP, bahwa Indonesia memiliki pulau bernama sebanyak 15.056 
pulau-pulau besar dan kecil, serta luas wilayah sekitar 7.7 juta $\mathrm{km}^{2}$, dimana 2/3nya merupakan perairan dengan luas lebih dari 5.8 juta $\mathrm{km}^{2}$ yang terdiri dari laut teritorial dengan luas 0.8 juta $\mathrm{km}^{2}$, laut nusantara 2.3 juta $\mathrm{km}^{2}$ dan ZEE 2.7 juta $\mathrm{km}^{2}$, serta memiliki garis pantai sepanjang lebih dari $81.000 \mathrm{~km}^{2}$, dan Zona Ekonomi Eksklusif (ZEE ) selebar $200 \mathrm{mil}^{2}{ }^{1}{ }^{1}$

Wilayah laut Indonesia menyimpan banyak potensi kekayaan laut yang sangat berlimpah. ini dikarenakan Indonesia memiliki perairan laut yang luas. Kawasan tersebut diperkirakan menyimpan kekayaan sumberdaya ikan sebesar 6,4 juta ton pertahun. ${ }^{2}$ Namun upaya eksploitasi berlebihan dan aksi pencurian ikan secara tidak patut dalam proses pengambilannya, seperti menggunakan bahan peledak bahkan sistem teknologi yang mengambil tanpa batas, mengancam potensi kekayaan tersebut.

Laut Indonesia yang merupakan hampir 75 persen $^{3}$ daerah kedaulatan Indonesia yang sangat luas ini, masih diabaikan dalam proses penjagaannya oleh semua pihak yang memiliki tanggungjawab dalam tugasnya menjaga perairan Indonesia. Ini terbukti dari penegakan hukum yang masih lemah dan bahkan ada daerah laut yang tidak pernah sama sekali terjamah oleh patroli aparat TNI Angkatan Laut maupun Polisi Air. Kondisi menjaga keamanan perairan laut itu memberikan kekhawatiran atas kelangsungan Negara maritim yang berdaulat, hingga menyebabkan tidak terkendalinya tindak kejahatan di laut Indonesia, dan membuat kesempatan para pelaku illegal fishing menjadi leluasa melakukan perbuatan kejahatan di laut Indonesia.

Indikasi adanya Illicit Enrichment dalam Illegal Fishing ini menjadi permasalahan yang paling serius untuk ditanggapi dan di berantas secara total dan universal, karena sesuai dengan informasi dari "Cerita Pejabat Polri yang Menolak Suap Rp 5 M dari Kapal Pelaku Illegal Fishing", 4 menjadi acuan bagaimana para pelaku Illegal Fishing melakukan permudahan dan perlancaran terhadap aksi yang dilakukan untuk mengeksploitasi hasil sumber daya laut, khususnya ikan. Tindakan yang mereka lakukan ini untuk memberikan suap kepada penegak hukum yang saat itu menangkap mereka di perairan dan menahan mereka sementara. Upaya yang mereka lakukan untuk melepaskan diri beserta kapal dan isinya tersebut dengan mencoba melakukan koordinasi kebijakan dengan kepala atau pimpinan penegak hukum dengan cara memberi kompensasi, yakni memberikan uang 5 Milyar, agar mereka di lepaskan dan di berikan dokumen perizinan dari kapal perikanan menjadi kapal pelayaran, apalagi pada waktu itu telah tertangkap 134 kapal yang melakukan Illegal Fishing, akan menjadi 5 milyar x $134=670$ milyar. $^{5}$

\footnotetext{
1 Anonim, Ilmu Pengetahuan, tersedia dalam http://ilmupengetahuanumum.com/10-negara-kepulauan-terbesardi-dunia, [diakses, 01 Desember 2016]

2 Anonim, Sekretaris Kabinet, setkab.go.id/potensi-besar-perikanan-tangkap-indonesia, [diakses, 01 Desember 2016]

3 Anonim, Bem Indonesia, tersedia dalam bemindonesia.or.id/.../Kajian-Illegal-Fishing-dan-Kedaulatan-Laut, [diakses, 29 November 2016]

Anonim, Detik, tersedia dalam http://news.detik.com/berita/2897563/cerita-pejabat-polri-yang-menolaksuap-rp-5-m-dari-kapal-pelaku-illegal-fishing, [diakses, 29 November 2016]

${ }^{5}$ Ibid.
} 
Perbuatan dan tindakan para pelaku Illegal Fishing ini, telah memberikan suatu gambaran tentang modus dan cara-cara yang negatif, dengan maksud agar di kemudian hari mereka melakukan Illegal Fishing dapat termudahkan dan terlancarkan. Sebagaimana penulis mendapatkan informasi dari cerita yang disampaikan oleh Kombes Pol. John Hendri yang sudah di paparkan dalam forum diskusi yang diadakan Korps Alumni Himpunan Mahasiswa Islam (KAHMI) bertajuk "Quo Vadis Penegakkan Hukum di Indonesia: Antara Cita dan Fakta", 6 di Jalan Turi, Kebayoran Baru, Jakarta Selatan. Hal ini akan memberikan sebuah gambaran tentang adanya modus bahwa banyak hal yang banyak terjadi dalam upaya-upaya dari pelaku Illegal Fishing untuk memperlancar dan mempermudah tindakan dalam mengeksploitasi sumber daya laut, khususnya ikan.

Usaha pemerintah dalam menaggulangi upaya oknum pejabat yang melakukan Illicit Enrichment ini, terkait dengan adanya upaya penanggulangan Illegal Fishing yang sebenarnya sedang dilakukan upaya penegakkan hukum oleh pemerintah. Ini tidak terlepas dari Menteri Kelautan dan Perikanan yang bertangan dingin mengatasi persoalan kemaritiman, yang diberitakan dalam informasi di Sindonews.com. Menteri Kelautan dan Perikanan Susi Pudjiastuti mengungkapkan, modus baru aksi penangkapan ikan secara ilegal (illegal unreported unregulated/IUU fishing) di perairan Indonesia, agar dapat kembali melakukan aksi penangkapan ikan secara ilegal ${ }^{7}$.

Adanya instruksi Presiden secara khusus dan meminta institusi pemerintahan lainnya, seperti Pusat Pelaporan Analisis Transaksi Keuangan (PPATK), untuk menelusuri aliran dana para pelaku illegal fishing. Koordinasi antara kementerian-kementerian dengan PPATK juga sangat diperlukan, sehingga benar-benar tahu mengenai data-data illegal fishing yang harus diikuti dan dikawal. Arus keuangannya dan data keuangannya harus diketahui dilakukan seperti apa, sehingga tindakan yang dilakukan kementerian itu ada fakta-fakta yang dipakai," kata presiden. ${ }^{8}$

Tindakan yang dilakukan oleh para pejabat berwenang dalam penanganan tugas dan jabatannya, terindikasi Illicit Enrichment ini, termyata terdapat juga peran lain, selain para petugas yang berwenang menangani urusan dimaksud, yaitu ada pengusaha atau elemen masyarakat yang terkait dalam tindakan-tindakan Peningkatan Kekayaan secara tidak sah (Illicit Enrichment) yang dengan pelaku Illegal Fishing. Sebagaimana yang dipaparkan oleh Menteri Kelautan dan Perikanan Susi Pudjiastuti di dalam "Sejumlah menteri Kabinet Kerja Presiden Jokowi merapat ke gedung Badan Pengkajian Penerapan Teknologi BPPT di

\footnotetext{
6 Anonim, Detik, tersedia dalam https://news.detik.com/berita/d-2897581/cerita-kombes-john-hendri-yangtolak-suap-miliaran-rupiah-dari-kapal-illegal-fishing, [diakses, 29 November 2016]

7 Anonim, Sindonews, tersedia dalam http://ekbis.sindonews.com/read/1069589/34/menteri-susi-ungkap-modusbaru-aksi-illegal-fishing-145016 9754 , [diakses, 29 November 2016]

8 Anonim, Beritasatu, tersedia dalam http://www.beritasatu.com/nasional/263409-jokowi-instruksikan-menterisusi-terus-berantas-illegal-fishing. html, [diakses, 29 November 2016]
} 
kawasan Thamrin, Jakarta Pusat. Rapat membahas pemberantasan praktik illegal fishing atau pencurian ikan yang marak terjadi di Indonesia". ${ }^{9}$

Menurut Menteri Perikanan dan Kelautan bahwa Investor asing sudah dilarang untuk investasi tangkap ikan di Indonesia. Sebab jika diperbolehkan, maka terlalu banyak kerugian daripada keuntungannya untuk Indonesia. Menteri Kelautan dan Perikanan, Susi Pudjiastuti, menyebut bebasnya kapal asing melaut di Indonesia membuat korupsi makin marak. Suap pun terjadi di berbagai lapisan masyarakat. "Memang ada beberapa pengusaha, tokoh masyarakat, pejabat, aparat, dan lain-lain yang dapat fee dari kegiatan bisnis penangkapan ikan kapal-kapal asing". ${ }^{10}$

Merujuk pada kondisi tersebut, pada tahun 2000, Perserikatan Bangsa-Bangsa mulai menginisiasi lahirnya komisi ad hoc ${ }^{11}$ untuk merumuskan kerangka acuan negosiasi suatu produk hukum internasional dalam upaya pencegahan dan pemberantasan korupsi ${ }^{12}$. Berdasarkan Resolusi Nomor 55/188 Tanggal 20 Desember 2000, komisi ini membentuk tim ahli antar pemerintah guna mulai mengkaji transfer dana illegal dan pengembalian dana ke Negara asal. Ini menjadi sebuah langkah awal dalam rangka perumusan konvensi anti korupsi.

Terjadi kemajuan yang cukup siginfikan dalam upaya perumusan konvensi anti korupsi, terbukti pada tahun 2003 lahir sebuah Konvensi PBB melawan korupsi (United Nation Convention Against Corruption) yang disahkan di Merida Mexico ${ }^{13}$. Indonesia merupakan salah satu negara yang turut serta menandatangani dan meratifikasi UNCAC melalui UndangUndang Nomor 7 Tahun 2006 tentang Pengesahan UNCAC. Sebagai Negara yang turut meratifikasi konvensi tersebut, Indonesia mempunyai variasi kewajiban dan kebijakan tertentu, misalnya terkait Ellicit Enrichmen yang diatur dalam Pasal 20 UNCAC, kewajiban Indonesia terlihat dalam frasa berikut :

“......., each party shall consider adopting such legislative and other measures as may be necessary to establish as a criminal offence, ....."

\footnotetext{
9 Anonim, Korda, tersedia dalam http://www.kordanews.com/index.php/2016/08/08/susi-sebut-ada-pejabathingga-tokoh-masyarakat-terima-uang-dari-kapal-asing/, [diakses, 29 November 2016]

10 Ibid.

11 Resolusi Nomor 56/260 komisi ini selesai menjalankan tugasnya pada akhir tahun 2003 di dalam buku Policy Paper Indonesia Corruption Watch, Implementasi dan Pengaturan Illicit Enrichment (Peningkatan Kekayaan secara tidak sah) di Indonesia, 2014, hal.17

12 Resolusi Umum Nomor 55/61 tanggal 4 Desember 2000, di dalam buku Policy Paper Indonesia Corruption Watch, Implementasi dan Pengaturan Illicit Enrichment (Peningkatan Kekayaan secara tidak sah) di Indone sia, 2014, hal.17

13 Konvensi ini di adopsi berdasarkan General Assembly dengan Resolusi Nomor 58/4 tanggal 31 Oktober 2003 yang terdiri dari 8 BAB dan 70 pasal di dalam buku Policy Paper Indonesia Corruption Watch, Implementasi dan Pengaturan Illicit Enrichment (Peningkatan Kekayaan secara tidak sah) di Indonesia, 2014, hal.18
} 
Frasa kalimat "each party shall consider adopting" bermakna mempunyai ketentuan wajib setingkat dengan perintah ${ }^{14}$. Artinya, Indonesia bertanggung jawab untuk menyiapkan prioritas langkah-langkah legislasi sebagai kewajiban setingkat perintah (mandatory) Negara anggota yang ikut meratifikasi konvensi tersebut. Sifat ketentuan (provisi) legislasi sebagai kewajiban Negara anggota tidaklah mempunyai kesamaan tingkatan. Ada 3 tingkatan sifat ketetapan konvensi yang meliputi: ${ }^{15}$

1. Perintah (absolute mandatory provision dan kondisi khusus).

2. Upaya-upaya keras negara anggota untuk mengadopsi.

3. Upaya-upaya pilihan.

Dalam peraturan dan konvensi internasional apa yang dilakukan oleh para pelaku Illicit Enrichment ini dapat terjerat sanksi maupun hukuman. Adanya fenomena yang belum pernah terjadi sebelumnya dalam sejarah Indonesia dalam proses pemberantasan Illegal Fishing yang mengakibatkan banyaknya keterkaitan dalam hubungannya dengan para pelaku Illegal Fishing . hal ini terkait dengan para aparat penegak hukum dan pejabat pemerintah terkait, hingga elemen masyarakat di dalamnya. Untuk itu perlu adanya konsekuensi dalam tindakan para pelaku dalam negeri (anak bangsa) yang menghancurkan bangsanya sendiri melalui Illicit Enrichment, dengan hukuman dan sanksi yang seberat-beatnya, hingga masyarakat Indonesia secara keseluruhan dapat menikmati dan mendapatkan hasil yang optimal dari sumber-sumber daya alam di Indonesia, sesuai amanah dari ketentuan hukum dasar yaitu Pasal 33 UUD 1945 Negara Kesatuan Republik Indonesia.

\section{B. RUMUSAN PERMASALAHAN}

Berdasarkan uraian mengenai latar belakang tersebut, penulis ingin melakukan penelitian guna menjawab beberapa pertanyaan, diantaranya :

1. Bagaimana tanggungjawab hukum dan peran pejabat pemerintah maupun swasta yang melakukan illicit enrichment pada pelaku illegal fishing dalam mengeksploitasi sumber daya laut Indonesia?

\footnotetext{
14 Legislative guide for implementation of the UNCAC part 3 number 12 "whenever the phrase "each state party shall adopt is used, the reference is to a mandatory provision. otherwise, the language used in the guide is shall consider adopting" or "shall endeavour to, which means that states are urged to consider adopting a certain measure and to make a genuine effort to see whether it would be compatible with their legal system. for entirely optional provisions, the guide employs the term "may adopt" (setiap kali frasa "setiap negara pihak harus mengadopsi digunakan, referensi adalah ketentuan wajib. sebaliknya, bahasa yang digunakan dalam panduan ini wajib mempertimbangkan untuk mengambil" atau "akan berusaha untuk, yang berarti bahwa negara-negara didesak untuk mempertimbangkan mengadopsi tertentu mengukur dan membuat upaya tulus untuk melihat apakah itu akan kompatibel dengan sistem hukum mereka. untuk ketentuan seluruhnya opsional, panduan mempekerjakan istilah "dapat mengadopsi") di dalam buku Policy Paper Indonesia Corruption Watch, Implementasi dan Pengaturan Illicit Enrichment (Peningkatan Kekayaan secara tidak sah) di Indonesia, 2014, hal. 18

${ }_{15}$ Legislative guide for implementation of the UNCAC para 3 number 10 di dalam buku Policy Paper Indonesia Corruption Watch, Implementasi dan Pengaturan Illicit Enrichment (Peningkatan Kekayaan secara tidak sah) di Indonesia, 2014, hal.18
} 
2. Bagaimana peran penegak hukum dalam menegakkan hukum di Perairan Indonesia?

\section{METODE PENELITIAN}

\section{Tipe dan Sifat Penelitian}

Penelitian ini merupakan penelitian normatif dengan menggunakan Statute Approach (Pendekatan Undang-Undang) dan Case Approach (Pendekatan Kasus). Sedangkan apabila ditinjau dari metodenya, penelitian ini termasuk dalam penelitian deskriptif kualitatif. ${ }^{16}$

Bahan Hukum yang digunakan yaitu norma ataupun kaidah dasar hukum internasional dan peraturan perundang-undangan serta konvensi-konvensi internasional yang memiliki kekuatan mengikat secara yuridis seperti United Nation Convention Against Corruption, United Nation Convention on the Law of the Sea 1982, Convention for the Suppression of Unlawful Acts Against the Safety of Maritime Navigation 1988, Rome Statute dan lain sebagainya;

\section{Teknik Pengumpulan Data}

Dalam penelitian ini penulis akan menggunakan teknik pengumpulan data dengan studi pustaka (Library Research). Teknik pengumpulan data ini dilakukan dengan cara membaca, mengkaji, dan membuat catatan dari buku-buku, peraturan PerundangUndangan, dokumen serta tulisan-tulisan yang berhubungan dengan masalah yang menjadi obyek penelitian.

\section{Teknik Analisis Data}

Teknik analisis data yang digunakan oleh penulis dalam penelitian ini adalah analisis logis, sistematis, dan yuridis.

\section{PEMBAHASAN}

1. Pejabat Pemerintah maupun Swasta yang melakukan Illicit Enrichment pada Pelaku Illegal Fishing dalam Mengekploitasi Sumber Daya Laut Indonesia

Ide mengenai Indonesia sebagai negara kepulauan mulai diperkenalkan melalui literasi sejarah dan diperkokoh pada tanggal 13 Desember 1957 melalui lahirnya Deklarasi Djuanda. Deklarasi Djuanda berisi pernyataan kepada masyarakat internasional bahwa Indonesia terdiri dari ribuan pulau sebagai satu kesatuan di bawah kedaulatan Negara Kesatuan Republik Indonesia (NKRI) serta penetapan garis batas territorial dengan lebar 12 mil diukur dari garisgaris yang menghubungkan titik-titik ujung terluar pada pulau-pulau di Indonesia, yang kemudian diperkuat dengan Undang-Undang Nomor 4 Perpres Tahun 1960 tentang Perairan Indonesia dan diatur lebih lanjut dalam Peraturan Pemerintah Nomor 8 Tahun 1928, dan

16 Soerjono Soekanto \& Sri Mamudji, Penelitian Hukum Normatif (Suatu Tinjauan Singkat), Rajawali Pers, Jakarta, 2001, hal. 10 
menjadikan luas wilayah laut Indonesia $2.027 .087 \mathrm{~km}^{2}$ (wilayah daratan) menjadi 5.193.250 $\mathrm{km}^{2}$ dan penambahan wilayah perairan nasional sebesar $3.166 .163 \mathrm{~km}^{2}{ }^{17}$

Dengan kondisi di atas banyak permasalahan penegakkan hukum terkait luasnya perairan Indonesia salah satunya adalah permasalahan hukum terkait dengan tindak pidana korupsi. Korupsi telah menjadi musuh bagi setiap negara, dimana korupsi sering disebut sebagai kejahatan luar biasa (extra ordinary crime), karena praktik korupsi telah tumbuh menjadi duri dalam daging bagi ketahanan suatu bangsa dan negara. Korupsi memberikan dampak yang sangat luas, diantaranya adalah dapat melanggar hak sosial ekonomi masyarakat yang merupakan bagian dari Hak Asasi Manusia (HAM).

Dengan demikian, pemberantasan korupsi haruslah dilakukan dengan cara yang luar biasa (extra ordinary measure) mengingat seperti yang telah disebutkan diatas, korupsi merupakan kejahatan yang luar biasa itu memiliki keterkaitan dengan menggunakan instrumen hukum yang luar biasa pula (extraordinary instrument). Salah satu instrument hukum yaitu dibutuhkan untuk memerangi korupsi adalah aturan khusus yang dapat merampas aset atau kekayaan penyelenggara negara yang dianggap tidak wajar (illicit enrichment). Merujuk pada definisi umum, llicit enrichment diartikan sebagai tindakan memperkaya diri sendiri secara tidak sah melalui adanya peningkatan asset atau kekayaan dalam jumlah yang cukup besar dari seorang pejabat publik, dan peningkatan kekayaan tersebut tidak dapat dijelaskan asal-muasalnya atau sumbernya yang sah menurut hukum.

Dalam pendapat Gandjar Laksmana Bonaprapta ${ }^{18}$ menjelaskan unsur-unsur utama illicit enrich ment adalah sebagai berikut :

a. Subjeknya adalah pejabat public atau pegawai negeri atau penyelenggara negara.

b. Memperkaya diri/memiliki kekayaan yang meningkat atau bertambah secara signifikan.

c. Ia tidak dapat menjelaskannya secara wajar (peningkatan kekayaan itu).

d. Peningkatan kekayaan itu terjadi akibat perbuatannya.

e. Perbuatan itu dilakukannya dengan sengaja.

Dalam pendapat lain, Chandra Hamzah menyebutkan, pengaturan illicit enrichment lebih ditekankan pada aset ${ }^{19}$. Melihat keadaan laut Indonesia yang begitu luas lebih dari 5.8 juta $\mathrm{km}^{2}$ akan memberikan hal yang sangat mudah dilakukan oleh para penegak hukum yang jauh dari pengawasan. Tindakan yang dilakukan oleh penegak hukum perairan Indonesia akan memberikan kemudahan dan keleluasaan bagi pelaku illegal fishing untuk mengeksploitasi sumber daya laut. ini disebabkan adanya tindakan dan perbuatan yang mendukung pelaku illegal fishing.

\footnotetext{
${ }^{17}$ Departemen Kelautan dan Perikanan Sekretaris Jenderal Satuan Kerja Dewan Maritim Indonesia, Evaluasi Kebijakan Dalam Rangka Implementasi Konevensi Hukum Laut Internasional (UNCLOS 1982) di Indonesia, DKP, Jakarta, 2008, hal. 2

18 Policy Paper Indonesia Corruption Watch, Implementasi dan Pengaturan Illicit Enrichment (Peningkatan Kekayaan secara tidak sah) di Indonesia, 2014, hal.29

19 Ibid.
} 
Penting adanya pengawasan intensif dan berkala terhadap tugas dan kewajiban yang dilakukan oleh para penegak hukum dalam menjaga perairan Indonesia. Adanya pengawasan terhadap para penegak hukum diperlukan juga adanya operasi mendadak dari pusat untuk memberikan efek jera terhadap oknum pelaku penegak hukum yang melakukan tindakan permudahan kepada pelaku illegal fishing. Praktek illegal fishing tidak hanya dilakukan oleh pihak asing, tetapi juga oleh para nelayan atau pengusaha lokal. Praktek illegal fishing yang dilakukan oleh para nelayan atau pengusaha lokal dapat digolongkan menjadi tiga golongan: ${ }^{20}$

a. Kapal ikan berbendera Indonesia bekas kapal ikan asing yang dokumennya palsu atau bahkan tidak memiliki dokumen ijin;

b. Kapal Ikan Indonesia (KII) dengan dokumen aspal atau "asli tapi palsu" (pejabat yang mengeluarkan bukan yang berwenang, atau dokumen palsu);

c. Kapal ikan Indonesia yang tanpa dilengkapi dokumen sama sekali, artinya menangkap ikan tanpa ijin.

Perilaku yang tidak patut dilakukan oleh beberapa pengusaha swasta yang bermitra dengan oknum pejabat setempat, tidak hanya seperti yang dilakukan di atas saja, tapi juga adanya upaya mengeksploitasi sumber daya laut secara skala prioritas pengusaha, karena kebutuhan yang diinginkan oleh orang atau negara asing tanpa melewati bea cukai. Dalam hal ini akan menyebabkan hasil pendapatan Negara dan sumber daya laut tereksploitasi tanpa ada prosedur semestinya atau filter dari negara, terhadap sumber daya laut yang seharusnya tidak dieksploitasi karena dilindungi.

Perbuatan para oknum pejabat dan penegak hukum beserta keterlibatan dari pengusaha setempat juga adanya pengaruh dari keterbatasan Sumber Daya Manusianya yang mau bekerja dan menjalankan tugas di wilayah terpencil atau daerah yang kurang begitu mendapat perhatian dari pemerintah pusat. Keterbatasan infrastruktur dan fasilitas perairan (kapal perang/Boat) dari para penegak hukum juga memberikan pengaruh terhadap para oknum pejabat dan penegak hukum beserta pengusaha swasta dengan leluasa melakukan perbuatan melanggar hukum dengan memfasilitasi pelaku illegal fishing.

Pejabat pemerintah yang tidak berwenang memberikan dokumen palsu atau ijin fiktif dan kemudahan terhadap pelaku illegal fishing untuk melakukan eksploitasi terhadap sumber daya laut. Situasi tersebut akan memunculkan dampak untuk memperkaya diri pribadi seorang pejabat pemerintah dalam hasil bumi negara yang di peruntukkan oleh kemakmuran rakyat sesuai dengan Pasal 33 Undang Undang Dasar Tahun 1945.

Para pengusaha swasta yang memberikan kapal atau perahu beserta bendera Indonesia serta info dan dokumen yang didapat dari pejabat yang tidak berwenang, sehingga memudahkan para pengusaha swasta melakukan transaksi illlegal kepada pelaku illegal fishing dan melakukan pengeksploitasi secara besar-besaran terhadap salah satu sunber daya laut yang menjadi target penjualan terhadap konsumen asing tanpa melalui bea dan cukai.

20 Anonim, Politik Hukum Penaggulangan Tindak Pidana Perikanan, tersedia dalam http://download.portalgaruda.org/article.php?article $=417397 \&$ val $=8102 \&$ title $=$ politik\%20hukum\%20penangg ulangan\%20tindak\%20pidana\%20perikanan, [diakses, 29 November 2016] 
Secara faktual, Indonesia memang belum mampu untuk mengamankan dan melindungi wilayah perairannya dari pencurian ikan (illegal fishing) yang dilakukan oleh kapal-kapal asing akibat belum memadainya tenaga, sarana dan prasarana untuk menjaga sekitar 6 juta $\mathrm{km}^{2}$ wilayah laut Indonesia. ${ }^{21}$ Selain itu, telah terjadi penggandaan perizinan atau lisensi penangkapan ikan oleh kapal-kapal asing, sehingga adakalnya kapal-kapal asing tersebut mengantongi ijin, tapi ijin tersebut palsu,

Selain kendala yang dihadapi oleh pemerintah terkait permasalahan legalitas ijin, terkait koordinasi pengawasan antar instansi kelautan yang tidak optimal, sosialisasi dan penafsiran hukum yang ada masih ditafsirkan secara berbeda, sehingga masih cukup banyak persoalan lain seperti minimnya sumber daya manusia sebagai tenaga pengawas, juga minimnya sarana dan prasarana penunjang operasional seperti kapal untuk patroli yang sesuai dengan kebutuhan (ukuran kapal, kecepatan kapal, jenis kapal dan sebagainya). ${ }^{22}$

Tarkait kebutuhan Infrastruktur pertahanan dan keamanan ada 3 (tiga) elemen penting terkait infrastruktur yang perlu ditingkatkan yakni: ${ }^{23}$

a. Penambahan unsur-unsur patroli yang berupa kapal dan pesawat pengintai/patroli maritim jarak sedang, lengkap dengan logistik di pangkalan depan/aju.

b. Pengintegrasian infrastruktur sistem informasi dan komunikasi data keamanan laut.

c. Peningkatan pembangunan kapasitas sumber daya manusia dalam mendukung kegiatan penegakan hukum di laut.

Sebagai negara kepulauan, sangat wajar jika wilayah Indonesia dikelilingi oleh wilayah perairan yang cukup luas. Dengan wiayah perairan yang cukup luas, sangat mungkin wilayah perairan Indonesia menjadi obyek pencurian kekayaan alam, seperti pencurian ikan dan sejenisnya. Illegal fishing menurut dokumen International Plan of Action-Food and Agriculture Organization of the United Nations (IPOA-FAO) terbagi dalam beberapa kategori yaitu: ${ }^{24}$

a. Kegiatan yang dilakukan oleh kapal-kapal nasional maupun asing di wilayah yuridiksi negara tanpa izin, atau bertentangan dengan hukum dan peraturan perundang-undangan negara tersebut.

b. Dilakukan oleh kapal berbendera negara anggota organisasi perikanan regional, tetapi kegiatannya bertentangan dengan konservasi dan pengelolaan yang telah ditetapkan oleh organisasi tersebut dan negara yang dinyatakan oleh bendera tersebut atau bertentangan dengan hukum internasional yang berlaku.

21 Anonim, Direktorat Pendayagunaan Pulau-Pulau Kecil, tersedia dalam http://www.ppkkp3k.kkp.go.id/ver2/news/read/115/membangun-kelautan-untuk-mengembalikan-kejayaan-sebagai-negara-

22 maritim.html, [diakses, 29 November 2016]

Ibid.

23 Anonim, Academia, tersedia dalam http://www.academia.edu/13120162/penegakan_hukum_laut_terhadap_illegal_fishing, $\quad$ [diakses, 29 November 2016]

24 "International Plan Of Action To Prevent, Deter And Eliminate Illegal, Unreported And Unregulated Fishing", tersedia dalam http://www.fao.org/docrep/003/y1224e/y1224e00, lihat juga abstraksi IPOA-FAO adalah instrumen swadaya yang berlaku untuk semua negara dan entitasnya dan untuk semua nelayan. 
c. Pelanggaran hukum nasional atau kewajiban internasional, termasuk oleh negara-negara yang melakukan kerjasama dengan organisasi pengelolaan perikanan regional.

Secara umum, Undang-Undang terkait perikanan dan penangkapan ikan dapat dikategorikan dalam tiga kelompok yakni, (1) Illegal fishing yaitu kegiatan penangkapan ikan secara illegal di perairan wilayah atau ZEE suatu negara, atau tidak memiliki ijin dari negara tersebut; (2) Unregulated fishing yaitu kegiatan penangkapan di perairan wilayah atau ZEE suatu negara yang tidak mematuhi aturan yang berlaku di negara tersebut; dan (3) Unreported fishing yaitu kegiatan penangkapan ikan di perairan wilayah atau ZEE suatu negara yang tidak dilaporkan baik operasionalnya maupun data kapal dan hasil tangkapannya. Praktek terbesar dalam IUU fishing pada dasarnya adalah poaching atau penangkapan ikan oleh negara lain tanpa ijin dari negara yang bersangkutan atau dengan kata lain, pencurian ikan oleh pihak asing alias illegal fishing.

Pada prakteknya keterlibatan pihak asing dalam pencurian ikan dapat digolongkan menjadi dua yaitu: ${ }^{25}$

a. Pencurian semi-legal, yaitu pencurian ikan yang dilakukan oleh kapal asing dengan memanfaatkan surat ijin penangkapan legal yang dimiliki oleh pengusaha lokal, dengan menggunakan kapal berbendera lokal atau bendera negara lain. Praktek ini tetap dikatagorikan sebagai illegal fishing, karena selain menangkap ikan di wilayah perairan yang bukan haknya, pelaku illegal fishing ini tidak jarang juga langsung mengirim hasil tangkapan tanpa melalui proses pendaratan ikan di wilayah yang sah. Praktek ini sering disebut sebagai praktek "pinjam bendera" (Flag of Convenience; FOC).

b. Pencurian murni illegal, yaitu proses penangkapan ikan yang dilakukan oleh nelayan asing dan kapal asing tersebut menggunakan benderanya sendiri untuk menangkap ikan di wilayah suatu negara.

Praktek illegal fishing tidak hanya dilakukan oleh pihak asing, tetapi juga oleh para nelayan atau pengusaha lokal. Praktek illegal fishing yang dilakukan oleh para nelayan/pengusaha lokal dapat digolongkan menjadi tiga golongan: ${ }^{26}$

a. Kapal ikan berbendera Indonesia bekas kapal ikan asing yang dokumennya palsu atau bahkan tidak memiliki dokumen ijin;

b. Kapal Ikan Indonesia (KII) dengan dokumen aspal atau "asli tapi palsu" (pejabat yang mengeluarkan bukan yang berwenang, atau dokumen palsu);

c. Kapal ikan Indonesia yang tanpa dilengkapi dokumen sama sekali, artinya menangkap ikan tanpa ijin.

\section{Penegak Hukum dalam Menegakkan Hukum di Perairan Indonesia}

Melakukan penegakan hukum di wilayah perairan Indonesia memangtidak mudah dikarenakan luas lautan yang banyak berbagai tantangan. Terdapat beberapa faktor yang

25 Anonim, Lingkungan, tersedia dalam https://lingkunganitats.wordpress.com/2014/12/25/kasus-pencurianikan-di-wilayah-indonesia/, [diakses, 01 Desember 2016]

26 Anonim, Politik Hukum Penaggulangan Tindak Pidana Perikanan, Op. Cit 
menyebabkan timbulnya Illegal fishing di perairan Indonesia, baik secara langsung maupun tidak langsung, berikut data penyebab Illegal fishing menurut Kementerian Kelautan dan Perikanan Indonesia ${ }^{27}$ :

a. Span of control yang sangat luas sehingga pengawasan menjadi tidak mudah;

b. Kemampuan armada pengawasan laut Indonesia masih sangat terbatas;

c. Law Enforcement yang masih lemah, mulai dari instansi penegak hukum dan instansi pemberi ijin masalah perikanan yang melindungi aktifitas Illegal fishing. Terlihat pada putusan hukum atas tindak pidana Illegal fishing yang tidak tegas;

d. Lemahnya peraturan mengenai keberadaan kapal ikan asing, sehingga masih membiarkan akan keberadaan kapal asing tersebut di wilayah yuridiksi perairan Indonesia;

e. Lemahnya kemampuan sumber daya nelayan, karena armada penangkapan ikan dan penguasaan teknologi yang masih tergolong sederharna dengan kapal ukuran kecil yang berdaya jelajah kecil dan tidak dapat berlayar dalam jangka waktu lama.

Di tengah tantangan illegal fishing, kekuatan maritim kita diprediksi akan meningkat dalam pembangunan wilayah perairan menuju komitment kekuatan perairan maritime Indonesia. Indonesia sudah seyogyanya memiliki kekuatan pengawal di lautan yang berfungsi sebagai penghubung, pemersatu, dan perekat negara kepulauan. Semboyan jalesveva jayamahe bisa diterjemahkan sebagai postur kekuatan TNI AL yang kuat, besar dan profesional. Embrionya mulai menampakkan tunas dan semakin membentuk patron itu, dimana kini TNI AL sedang dan akan menuju tahapan strategis, menuju kekuatan tiga armada tempur.

Ketika pelaksanaan peningkatan kekuatan kemaritiman sudah tegak dalam penerapan tanggungjawab hukum oleh para pejabat yang berwenang, maka kepulauan Indonesia yang mendapatkan julukan sebagai zamrud khatulistiwa, akan dikawal oleh kekuatan tiga armada tempur yang tangguh dan modern yang mampu memberikan kekuatan penangkal yang terukur, besar dan disegani. Saat ini TNI AL memiliki kekuatan dua armada tempur yaitu armada barat dan timur dengan alutsista utama 154 KRI dan 209 KAL, 2 divisi Marinir dan sebaran pangkalan yang merata. ${ }^{28}$

Prediksi kekuatan tiga armada itu adalah ${ }^{29}$ :

a. Armada Barat

Pangkalann utama di Tanjung Pinang dan Belawan, pangkalan pendukung Dumai, Batam, Natuna, Lhok Seumawe, Sabang, Padang, Mempawah. Jumlah KRI berkisar 8085 KRI dari berbagai jenis (Fregat, Korvet, KCR, LPD, LST). Wilayah pengawasan

27 Anonim, Academia, Op. Cit

28 Anonim, Alutsista, tersedia dalam http://analisisalutsista.blogspot.co.id/2011/01/serial-alutsista-2-tni-almenuju.html, [diakses, 01 Desember 2016]

${ }^{29}$ Ibid. 
Armada barat adalah Selat Malaka, Selat Singapura, Laut Natuna, Selat Karimata dan Pantai Barat Sumatera diperkuat dengan 3 Brigade Marinir.

b. Armada Tengah

Pangkalan utama di Surabaya dan Jakarta, pangkalan pendukung Makassar, Balikpapan, Tarakan, Bitung, Cilacap, Teluk Lampung dan Benoa. Armada Tengah diperkuat dengan 85-90 KRI dari berbagai jenis termasuk satuan kapal selam, kapal rumah sakit. Wilayah pengawasannya adalah Selat Sunda, Laut Jawa, Pantai Selatan Jawa, Selat Bali, Selat Lombok, Selat Makassar dan Laut Sulawesi. Armada Tengah diperkuat dengan 4 Brigade Marinir.

c. Armada Timur

Pangkalan utama di Ambon dan Kupang, pangkalan pendukung di Merauke, Jayapura, Sorong dan Ternate. Sebaran KRI berkisar antara 82-85 KRI dari berbagai jenis (Fregat, Korvet, Kapal Selam). Wilayah pengawasan adalah Laut Timor, Laut Arafuru, Laut Banda, Laut Maluku, Pantai Utara Papua. Mengingat kontur laut di wiayah ini adalah laut dalam maka KRI yang beroperasi adalah dari jenis Fregat dan Korvet. Armada Timur diperkuat dengan 3 Brigade Marinir. Jumlah seluruh KRI yang dimiliki 3 armada tempur itu berkisar $250 \mathrm{KRI}$.

Kepolisian Republik Indonesia didukung oleh TNI AL harus berupaya mengamankan daerah laut Indonesia dari Illegal Fishing, tetapi persoalanya dengan Alutsista yang terbatas tersebut dan berbanding terbalik dengan luas perairan Indonesia yang begitu luas tidaklah mungkin untuk dapat menjangkau titik-titik terluar Indonesia. kondisi tersebut harusnya Pemerintah menambah Alutsista terkhusus pada TNI Angkatan Laut agar lebih maksimal dalam mengawal perairan Indonesia. Para Penegak Hukum dalam hal ini yang melakukan penindakan kepada pelaku Illegal Fishing harus selalu senantiasa mengedepankan Penegakan Hukum yang tidak memberikan ruang bagi pelaku untuk dapat mengulangi kembali perbuatanya serta memberikan efek jera. Penegak hukum harus secara terbuka dan transparan terkait dengan penegakan hukum di Perairan Indonesia, agar supaya praktik-praktik mempermudah, membebaskan pelaku Illegal Fishing dengan cara melawan hukum tidak terjadi kembali. Sehingga proses penegakan hukum tidak dicederai oleh pihak-pihak yang tidak bertanggungjawab dan negara tidak dirugikan banyak hal atas kekayaan alam Negara Indonesia.

\section{E. PENUTUP}

\section{KESIMPULAN}

Dari uraian di atas diperlukan upaya tegas dalam penguatan hukum dalam wilayah kedaulatan NKRI melalui perairan dan penerapan hukum sesuai ketentuan Hukum yang berlaku di Indonesia dan ratifikasi yang dilakukan oleh Indonesia. Di bawah ini adalah yang perlu diperhatikan dalam penguatan hukum dari permasalahan yang disoroti oleh penulis : 
a. Upaya pemberantasan korupsi harus dilakukan dengan cara yang luar biasa (extraordinary measure) dan dengan menggunakan instrumen hukum yang luar biasa pula (extraordinary instrument).

b. Penegakkan hukum terhadap ketentuan Undang-Undang terkait harus meemiliki penguatan daya paksa terhadap pelaku illegal fishing, tanpa melihat kepentingan bagi rekomendasi para pejabat, dalam hal ini diperlukan petugas yang memiliki integritas dan keterlatihan dalam menjaga NKRI. diantaranya adalah melalui sebuah aturan khusus yang dapat merampas aset atau kekayaan penyelenggara negara yang dianggap tidak wajar (illicit enrichment). Cara ini bisa juga diterapkan untuk mengatasi kasus pencurian ikan yang sering merugikan keuangan negara.

\section{SARAN}

a. Hendaknya pemerintah mampu melakukan investigasi dengan turun ke lapangan untuk melihat secara langsung dan melakukan tindakan-tindakan pencegahan secara tegas terhadap para pelaku-pelaku Illicit Enrichment dan menindak para pelaku ini sesuai dengan hukum yang berlaku. Adanya efek jera perlu dilakukan dengan adanya tindakan sanksi hukum yang kuat terhadap para pelaku Illicit Enrichment dengan adanya hukuman yang berat.

b. Fungsi Control pemerintah dengan menempatkan sumber daya manusia serta sistem peningkatan pendapatan dan pemerataan ekonomi di seluruh bidang agar tidak muncul adanya kesempatan untuk mencari-cari pendapatan yang dilakukan oleh para penegak hukum secara illegal.

\section{DAFTAR PUSTAKA}

\section{Buku ;}

Departemen Kelautan dan Perikanan Sekretaris Jenderal Satuan Kerja Dewan Maritim Indonesia, Evaluasi Kebijakan Dalam Rangka Implementasi Konevensi Hukum Laut Internasional (UNCLOS 1982) di Indonesia, DKP, Jakarta, 2008;

Konvensi ini di adopsi berdasarkan General Assembly dengan Resolusi Nomor 58/4 tanggal 31 Oktober 2003 yang terdiri dari 8 BAB dan 70 pasal di dalam buku Policy Paper Indonesia Corruption Watch, Implementasi dan Pengaturan Illicit Enrichment (Peningkatan Kekayaan secara tidak sah) di Indonesia, 2014;

Policy Paper Indonesia Corruption Watch, Implementasi dan Pengaturan Illicit Enrichment (Peningkatan Kekayaan secara tidak sah) di Indonesia, 2014;

Policy Paper Indonesia Corruption Watch, Implementasi dan Pengaturan Illicit Enrichment (Peningkatan Kekayaan secara tidak sah) di Indonesia, 2014; 
Resolusi Nomor 56/260 komisi ini selesai menjalankan tugasnya pada akhir tahun 2003 di dalam buku Policy Paper Indonesia Corruption Watch, Implementasi dan Pengaturan Illicit Enrichment (Peningkatan Kekayaan secara tidak sah) di Indonesia, 2014;

Resolusi Umum Nomor 55/61 tanggal 4 Desember 2000, di dalam buku Policy Paper Indonesia Corruption Watch, Implementasi dan Pengaturan Illicit Enrichment (Peningkatan Kekayaan secara tidak sah) di Indonesia, 2014;

Soerjono Soekanto \& Sri Mamudji, Penelitian Hukum Normatif (Suatu Tinjauan Singkat), Rajawali Pers, Jakarta, 2001.

\section{Media Cetak dan Elektronik :}

Anonim,

Academia,

tersedia

dalam http://www.academia.edu/13120162/penegakan_hukum_laut_terhadap_illegal_fishing, [diakses, 29 November 2016];

Anonim, Alutsista, tersedia dalam http://analisisalutsista.blogspot.co.id/2011/01/serialalutsista-2-tni-al-menuju.html, [diakses, 01 Desember 2016];

Anonim, Bem Indonesia, tersedia dalam bemindonesia.or.id/.../Kajian-Illegal-Fishing-danKedaulatan-Laut, [diakses, 29 November 2016];

Anonim, Beritasatu, tersedia dalam http://www.beritasatu.com/nasional/263409-jokowiinstruksikan-menteri-susi-terus-berantas-illegal-fishing. html, [diakses, 29 November 2016];

Anonim, Detik, tersedia dalam http://news.detik.com/berita/2897563/cerita-pejabat-polriyang-menolak-suap-rp-5-m-dari-kapal-pelaku-illegal-fishing, [diakses, 29 November 2016];

Anonim, Detik, tersedia dalam https://news.detik.com/berita/d-2897581/cerita-kombes-johnhendri-yang-tolak-suap-miliaran-rupiah-dari-kapal-illegal-fishing, [diakses, 29 November 2016];

Anonim, Direktorat Pendayagunaan Pulau-Pulau Kecil, tersedia dalam http://www.ppkkp3k.kkp.go.id/ver2/news/read/115/membangun-kelautan-untuk-mengembalikankejayaan-sebagai-negara-maritim.html, [diakses, 29 November 2016];

Anonim, Ilmu Pengetahuan, tersedia dalam http://ilmupengetahuanumum.com/10-negarakepulauan-terbesar-di-dunia, [diakses, 01 Desember 2016]; 
Anonim, Korda, tersedia dalam http://www.kordanews.com/index.php/2016/08/08/susi-sebutada-pejabat-hingga-tokoh-masyarakat-terima-uang-dari-kapal-asing/, [diakses, 29 November 2016];

Anonim,

Lingkungan,

tersedia

dalam

https://lingkunganitats.wordpress.com/2014/12/25/kasus-pencurian-ikan-di-wilayahindonesia/, [diakses, 01 Desember 2016];

Anonim, Politik Hukum Penaggulangan Tindak Pidana Perikanan, tersedia dalam http://download.portalgaruda.org/article.php? article $=417397 \& v a l=8102 \&$ title $=$ politik \%20hukum\%20penanggulangan\%20tindak\%20pidana\%20perikanan, [diakses, 29 November 2016];

Anonim, Sekretaris Kabinet, setkab.go.id/potensi-besar-perikanan-tangkap-indonesia, [diakses, 01 Desember 2016];

Anonim, Sindonews, tersedia dalam http://ekbis.sindonews.com/read/1069589/34/menterisusi-ungkap-modus-baru-aksi-illegal-fishing-145016 9754 , [diakses, 29 November 2016];

International Plan Of Action To Prevent, Deter And Eliminate Illegal, Unreported And Unregulated Fishing", tersedia dalam http://www.fao.org/docrep/003/y1224e/y1224e00, lihat juga abstraksi IPOA-FAO adalah instrumen swadaya yang berlaku untuk semua negara dan entitasnya dan untuk semua nelayan. 